\title{
How Conservation GIS Leads to Rio de Janeiro, Brazil
}

\author{
Clinton Neil Jenkins ${ }^{1}$, Stuart L. Pimm² \& Maria Alice dos Santos Alves ${ }^{3}$
}

\author{
${ }^{1}$ Department of Biology, North Carolina State University, Raleigh, NC, United States of America \\ ${ }^{2}$ Nicholas School of the Environment, Duke University, Durham, NC, United States of America \\ ${ }^{3}$ Departamento de Ecologia, Universidade do Estado do Rio de Janeiro - UERJ, Rio de Janeiro, RJ, Brazil
}

\begin{abstract}
Success in conservation requires that everyone maximize his or her individual impact, because resources are limited and the challenge of saving biodiversity is great. Ten years ago, we asked how best a small, but energetic and passionate group could act to prevent bird extinctions in the Americas. We discuss our long-term approach to the problem and the resulting successful conservation actions and, in doing so provide a possible guide for others trying to focus their conservation efforts. Through a progressive series of intuitive GIS analyses, we showed that the Atlantic Forest has the highest concentration of threatened birds in the Americas. Within the Atlantic Forest, the state of Rio de Janeiro has the highest concentration of those threatened birds. Within Rio de Janeiro state, an isolated lowland forest fragment of a few thousand hectares stands out as the highest priority for preventing bird extinctions. We identified the creation of a small forest corridor to that fragment as the most effective action we could take to prevent bird extinctions, in all of the Americas. Today, we know that corridor as the Fazenda Dourada and the trees are growing back. That success was the result of a specific research and conservation agenda, one that is long-term, based on quantitative science, and guided by local conservation actors.
\end{abstract}

Key words: Biodiversity, Birds, Endangered, Extinction, Priorities.

\section{Introduction}

Success in conservation requires that everyone maximize his or her individual impact, because our resources are limited and the challenge of saving biodiversity is great. Deciding where and how one can be most effective though can be a vexing problem. Ten years ago, our research groups faced just this issue. We asked how best a small, but energetic and passionate group could act to prevent bird extinctions in the Americas. We discuss here our approach to the problem and the resulting successful conservation actions. Herein, we provide an explanation of our actions and, in doing so provide a possible guide for others trying to focus their conservation efforts.

Our focus on birds and their extinction was deliberate. Extinctions are forever, unlike many other environmental problems, which are potentially reversible. A cleared forest can grow back, but extinct species like the Dodo cannot return from the dead. We are experts on birds, and most qualified to conserve them rather than other taxa. Our

\footnotetext{
${ }^{*}$ Send correspondence to: Clinton N. Jenkins Department of Biology,

North Carolina State University, Zip Code 27695, Raleigh,

NC, United States of America

e-mail: clinton.jenkins@gmail.com
}

specialization on birds, however, stems from our knowing them so much better than other taxa. Of course, this specialization clearly requires us to address whether our actions would have been different if we had chosen different taxa. Finally, the Americas commend themselves because they are particularly rich in species, but also more readily accessible to us than other continents.

Through a progressive series of GIS analyses, we first narrowed our focus to the Brazilian Atlantic Forest, then to the state of Rio de Janeiro within the Atlantic Forest, and ultimately to a small, isolated lowland forest fragment of a few thousand hectares. Our conclusion was that this forest fragment had the highest concentration of endangered birds in the Americas while representing less than $0.0001 \%$ of its area. We identified the creation of a small forest corridor to that fragment as the most effective action we could take to prevent bird extinctions, in all of the Americas. Interestingly, connecting the forest fragments was a major priority of a local NGO that worked not on birds, but on a mammal - the golden lion tamarin.

Today, we know that corridor as the Fazenda Dourada and the trees are growing back as you read this paper. That success was the result of a specific research and conservation agenda, one that is long-term, based on quantitative science, and guided by local conservation actors. 


\section{Why the Atlantic Forest?}

To save species, one must first know where they are, and specifically where the ones at risk are. When we began, such knowledge did not yet exist for birds, at least not at a scale fine enough to guide the specific actions of a small conservation team. We had to generate the data and the answers ourselves.

Results of the first effort appeared in Manne et al. (1999). By analyzing the distributions of the passerine birds, a labor-intensive task that required the digitizing of thousands of hand-drawn maps in field guides, Manne et al. (1999) showed that birds threatened with extinction occur in a very narrow portion of the Americas. Most of the continental Americas actually has few or no birds at risk of extinction, even places with many species overall.

In recent years, high quality digital maps for all of the birds in the Americas, not just passerines, became available (Ridgely et al. 2007). This enabled a more complete and spatially refined analysis, the summary of which appears in Figure 1. By overlaying the maps for all birds, we see that a few parts of the Americas have many more species than do others (Figure 1a). Two regions stand above the
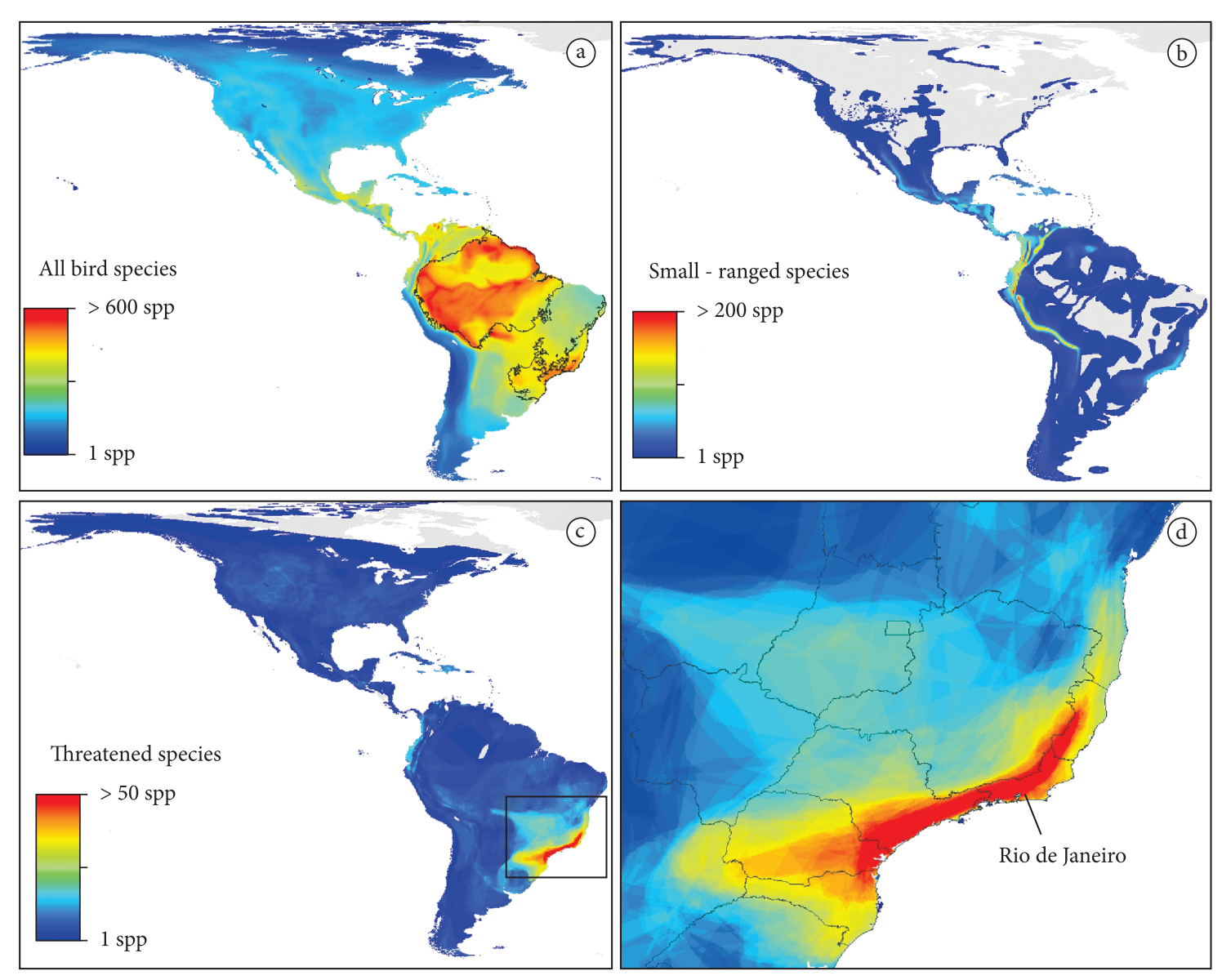

rest, the Amazon and the Atlantic Forest. There are other diverse areas, many of them smaller tropical forests in the Andes and Central America. Much of the Americas has far fewer species.

Figure 1c shows that the Atlantic Forest is the place to prevent the most species extinctions and not the Amazon, in general. By using the individualized species assessments from the IUCN Red List, we focused on the species known to be at risk of extinction, those considered threatened or endangered under the IUCN's formal assessment (IUCN 2010). The Atlantic Forest appears as the overwhelming center of extinction risk (Figure 1c). We can even narrow the conservation focus to the southeast portion of the Atlantic Forest, where there is a peak in the number of threatened birds (bright red in Figure 1c). The center of that region, with the highest concentration of threatened birds, is the state of Rio de Janeiro, Brazil (Figure 1d). No other area in the Americas comes close to the number of threatened bird species, and that is why we decided to act in Rio de Janeiro state to save birds. This first step eliminated more than $99 \%$ of the Americas from our focus.

To understand why, we must first look to the ecology of species and the histories of deforestation. Just as not

Figure 1. Species richness of all birds (a), small-ranged birds (b), threatened birds (c), and threatened birds in the southeast Atlantic Forest (d). The Amazon and Atlantic Forest ecoregions (Olson et al. 2001) are outlined in (a). The black box in panel (c) corresponds to the extent of panel D. Species diversity was derived from range map data in Ridgely et al. (2007). 
all places are equal in terms of their number of species, neither are the individual species themselves equal. Some are easier to drive extinct than others are. A primary factor in that extinction risk is geographic range size (Manne et al. 1999, for birds; Purvis et al. 2000, for mammals). All other things being equal, a species with a smaller range is more vulnerable to extinction than is a species with a larger range. Moreover, species with small geographical ranges tend to be locally less abundant within those ranges than species with large ranges - as Manne \& Pimm (2001) show for birds in the Americas. By looking at where these vulnerable species are, we gain information as to where extinctions are more likely, and thus possible areas on which to focus conservation efforts.

When looking only at birds with ranges smaller than the median range size $\left(\sim 400,000 \mathrm{~km}^{2}\right)$, we see a dramatically different pattern than that from all species (compare Figures 1a,b). The Amazon has few documented smallranged species whereas the Andes and the Atlantic Forest have many. We emphasize that Figure $1 \mathrm{~b}$ shows half of all bird species in the Americas, yet the seemingly most diverse place, the Amazon, is essentially absent. Most of the Americas, and even many other tropical forests, actually have few or none of the vulnerable small-ranged species. Patterns for small-ranged mammals and amphibians are similar (Pimm \& Jenkins 2005).

Parenthetically, some of this could be a problem associated with the maps presented here. At this scale, they do not precisely show the small-ranged species in riverine habitats (Vale et al. 2007), for example. Moreover, some of this pattern could be due to the lack of field studies in the Amazon compared to the Atlantic Forest. Small-ranged species tend to be the last ones discovered (Pimm et al. 2010; Joppa et al. 2011a, b). Nonetheless, future discoveries are unlikely to overturn such a dramatic difference.

The features of the species themselves are one of two parts of the explanation for the concentration of threatened species in the Atlantic Forest. The second part is that most of the Atlantic Forest has already been lost, having been cut and degraded for nearly 500 years (Dean 1996; Ribeiro et al. 2009; Fundação SOS Mata Atlântica \& INPE 2010). The precise amount estimated to remain depends on the specific study and methodology, mostly in terms of what counts as forest, but the estimates center around $10 \%$. The intersection of this massive habitat loss with a concentration of intrinsically vulnerable species leads to a massive center of extinction risk. Exactly this intersection underpins the idea of a biodiversity hotspot (Myers et al. 2000).

\section{Toward an Implementation Scale}

While Rio de Janeiro state represents just $0.15 \%$ of the Americas, it is still a large area for conservation, covering $\sim 43,700 \mathrm{~km}^{2}$. That is far larger than any protected area in the Atlantic Forest. Rio de Janeiro is the most forested of all the Brazilian states in the Atlantic Forest, with an approximate forested area of $8,075 \mathrm{~km}^{2}$ or $18.4 \%$ of the state (Fundação SOS Mata Atlântica \& INPE 2010). Yet, most of the forest remnants are in elevated areas compared to a few lowland areas and coastal ecosystems (Rocha et al. 2003), with most of the remnants smaller than 50 ha and being dispersed and isolated (Fidalgo et al. 2009). Moreover, the Rio de Janeiro landscape is very complex and the many threatened birds are again unevenly distributed (Alves et al. 2009b).

To identify a site of practical size for our team to act for conservation we needed a still finer scale. Now, identifying finer scale patterns of endangerment requires finer scale maps of where species occur, but our field knowledge was simply not good enough. For some species, there are only a few confirmed localities (e.g., Tijuca condita; Alves et al. 2008). Species are assumed to occur in much of the forest, but resources are not available to actually inventory every square kilometer, nor are such resources likely to become available. Our solution was to make ecologically based GIS models to extend what we did know about each species across the priority landscape of Rio de Janeiro. We only briefly describe the methods here, as we published the details elsewhere (Jenkins et al. 2010).

The first task was to define a list of species for which we wanted finer scale maps. As discussed earlier, not all species are of conservation concern. Some species have such large ranges that they will occur elsewhere even if they disappear entirely from Rio de Janeiro or even the Atlantic Forest. Others are not at risk of extinction because they are generalists and are able to adapt to anthropogenic disturbance. In our case, we considered only those species listed as threatened or endangered at the state, national, or global level, or that were endemic to the Atlantic Forest. We ignored $\sim 3 / 4$ of the bird species in the state.

The models we built were commensurate with the level of knowledge available for most vertebrates, but sophisticated enough to refine greatly the species range map. Step one took the known range of the species and buffered it by a short distance $(15 \mathrm{~km})$. This was to recognize two characteristics of range maps. First is that the georeferencing of any range map has some error, which becomes very important for narrow-ranged endemics, and especially so in a coastal state like Rio de Janeiro. Second, we preferred to risk a slight overestimate of the range of a species than to automatically exclude potential habitat.

Step two of the model eliminated areas outside the known elevation limits of the species. We used databases of known elevation limits for birds (e.g., Parker et al. 1996) plus supplemental sources for select species with more recent data. Details are in Jenkins et al. (2010).

Step three eliminated areas with obviously unsuitable land cover for each species. For instance, if a bird is forest dependent, then it is safe to eliminate areas of non-forest as habitat. Likewise, a species restricted to restinga (a sandy coastal plain habitat associated with the Atlantic Forest) 
will not occur in non-restinga areas, and thus we can safely eliminate those areas from that species' range map.

In step four, we eliminated forest fragments smaller than $1 \mathrm{~km}^{2}$. Such small fragments suffer local extinctions very quickly, being unable to maintain viable populations for more than a few years (Ferraz et al. 2003). We recognize that small forest fragments can serve a valuable role in reconnecting larger forest fragments that retain much of their biodiversity.

In essence, we did not model each species' habitat but instead eliminated those places that are certainly not viable habitat. This was similar in concept to our initial approach of eliminating parts of the Americas based on whether or not they have small-ranged or known threatened species. What remains is certainly still an overestimate, but it is a much smaller overestimate than that of the original continental-scale maps.

We intentionally did not use sophisticated species distribution models (Peterson et al. 2007). The data required to use such models are few for most species, and are almost never available for species at risk of extinction. Moreover, either through their rules or through their statistical assumptions, these models can obfuscate the simple, well-understood processes that ours include: broad geographical range and habitat choices, elevation, absence from small fragments.

Figure 2 summarizes the results, the richness of threatened birds draped over the topography of the state of Rio de Janeiro. The first obvious feature is that most of the state has no threatened birds (grey in Figure 2), for it has no remaining natural habitat to harbor them. Almost all of the threatened birds are forest-dependent. A second feature is that the central high elevations are low priority (blues), for while they do have threatened species, they overall have fewer than the lowlands. Across the state, the remaining lowland and medium elevation forests are what appear in shades of yellow, orange, and red, the higher priorities. One forest fragment stands out among all the rest, and that red fragment in the east of the map is União Biological Reserve (ReBio União).

Beginning with an area spanning two continents, we arrived at this single forest fragment of about three thousand hectares, eliminating $99.9999 \%$ of the Americas from our attention. It is one of the highest priority areas for bird conservation in the world.

\section{Implementing Conservation}

That priority forest fragment gained protection as a Biological Reserve to become Reserva Biológica União (ReBio União) in 1998. A Biological Reserve is a high level of protection in the Brazilian system of conservation units, and there is little more one could hope for in terms of legal protection. ReBio União is located in the coastal lowlands of Rio de Janeiro state $\left(22^{\circ} 36^{\prime}\right.$ to $22^{\circ} 12^{\prime} \mathrm{S}$; $42^{\circ} 12^{\prime}$ to $42^{\circ} 60^{\prime} \mathrm{W}$ ) (ICMBio $2008)$. It is 2,548 ha and covered mainly by forest except for 220 ha of pre-existing eucalyptus plantations (ICMBio 2008). The Leopoldina Railway Company formerly owned the land and they planted eucalyptus for fuel to run steam locomotives, explaining the presence of exotic eucalyptus trees in a biological reserve.

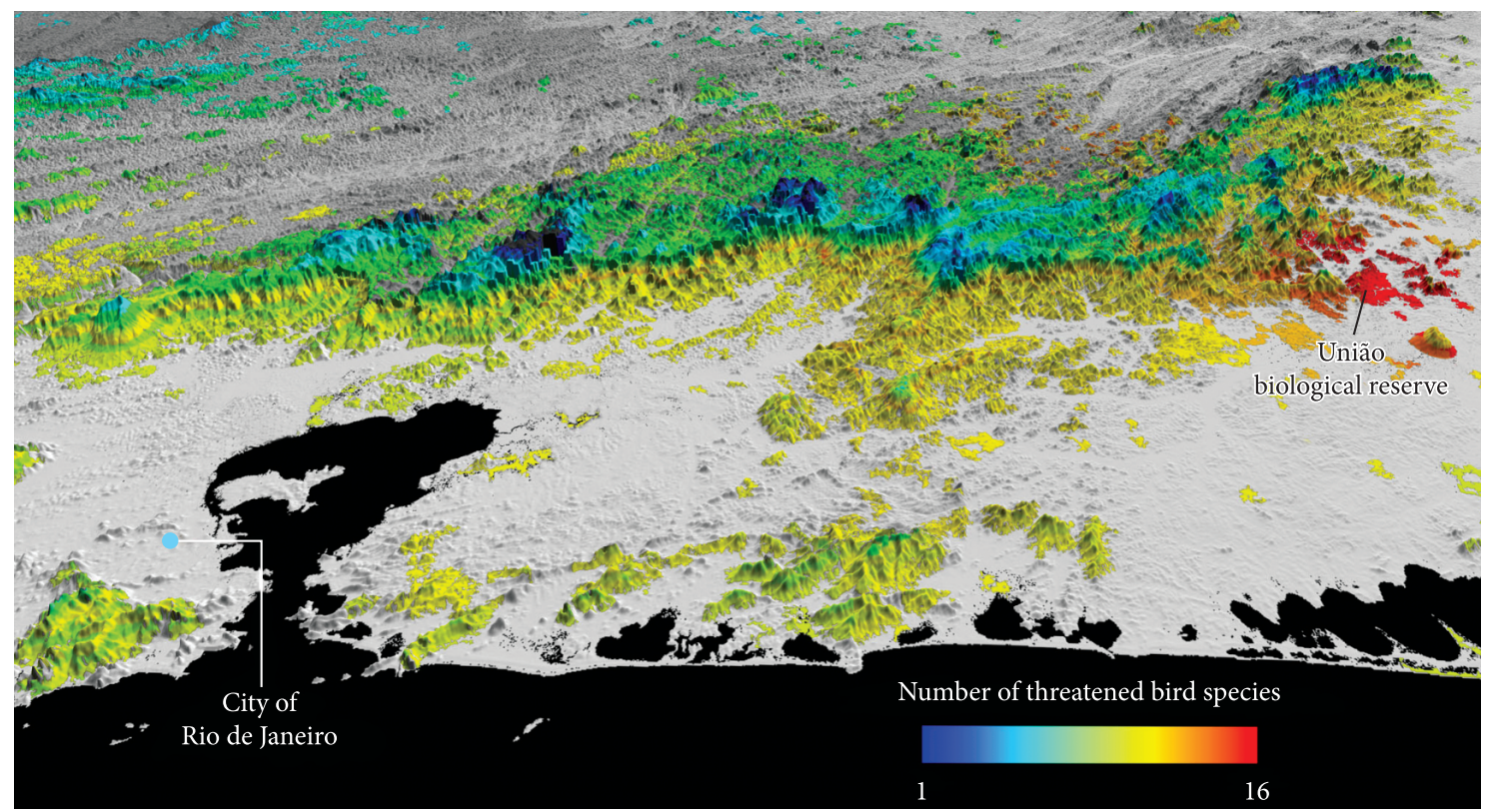

Figure 2. Distribution of threatened bird species in the state of Rio de Janeiro, Brazil. Most of the threatened bird species live in lowland or medium elevation forest fragments. Reconnecting these fragments to higher elevation forests is a major conservation priority. The red forest fragment in the eastern part of the state (right-hand side) is União Biological Reserve, the highest priority for bird conservation in the Americas. Photographs of the gap isolating this forest from other forest areas are in Figure 3. Gray areas no longer have forest. A version of this figured originally appeared in Scientific American (Pimm \& Jenkins 2005). 
Creating the reserve protected an important remnant of Atlantic Forest, many endangered birds, and particularly the endangered golden lion tamarin (Leontopithecus rosalia). Nevertheless, the reserve had a major conservation concern. It is a relatively small fragment and was isolated from all other forested areas. Cattle pasture surrounded the reserve, pastures that were often burned, threatening the remaining protected forest. Many previous studies have established the problems of isolated forest fragments, with the studies north of Manaus particularly influential (Laurence et al. 2011). In particular, we know that isolated forest fragments rapidly lose their species (Brooks et al. 1999; Ferraz et al. 2003). This was originally a connected landscape, with essentially the entire region covered in continuous forest. Re-connecting the fragments was an obvious priority for us - and one shared by our colleagues who worked on the golden lion tamarin.

ReBio União is strategically located, being adjacent to at least 3,000 ha of forest not yet integrated into the conservation system. The long-term solution was clear. There needed to be a corridor to that nearby forest and protection extended to the full area.

Solving the problem involved extensive time on the ground, not to do biological research, but to meet and talk with people. We met with the managers of ReBio União, local scientists, landowners, Brazilian and international conservation groups, but most importantly, we met with individual people. To all of them, we presented the story of why ReBio União was so important and why a corridor would be critical to long-term protection of species. We published scientific papers (Harris et al. 2005; Jenkins et al. 2010), book chapters in English and Portuguese (Jenkins 2003; Jenkins \& Pimm 2006; Alves et al. 2009a,b), and popular articles (Pimm \& Jenkins 2005).

After years of spreading the message, success came about because a small number of individuals and organizations committed to make it happen. They recognized the scientific argument, they knew the obstacles, and ultimately the needed land for the corridor was purchased, added to the reserve, and is being reforested. Many of those individuals remain anonymous, but instrumental to success were the Associação Mico-Leão-Dourado, Save the Golden Lion Tamarin, the IUCN National Committee of the Netherlands (www.iucn.nl), and SavingSpecies (www.savingspecies.org). The last two organizations raised approximately $1 / 3$ and $2 / 3$ rds of the money respectively as a grant to Associação Mico-Leão-Dourado to buy the land. An added incentive for the individual contributors was that not only would they be protecting species, but also the regrowing forest would offset their personal carbon emissions, a sort of forgiveness for their carbon $\sin$.

Efforts are now underway by the federal Chico Mendes Institute of Biodiversity Conservation (ICMBio) to continue the expansion of ReBio União. As well, the State Environmental Institute (INEA) is pursuing expansion of the nearby Parque Estadual dos Três Picos, which was already expanded in 2009 by 12,440 ha to a total of 58,790 ha. Both efforts are part of a planned connection between the lowlands and the mountains. One of the next steps is to include the forest to the west of ReBio União, the same forest to which the Fazenda Dourada corridor connects. This would nearly double the size of the official reserve. Ultimately, this connection will not only preserve habitats and species but also ecological processes, such as seasonal movements of birds along the altitudinal gradient.

\section{Discussion and Caveats}

Using a series of intuitive, yet simple GIS analyses, we showed that the Atlantic Forest has the highest concentration of threatened birds in the Americas. Within the Atlantic Forest, the state of Rio de Janeiro has the highest concentration of those threatened birds. Within Rio de Janeiro state, ReBio União stands out as the highest priority forest fragment for preventing bird extinctions. Our conclusion was that the single best place where we could prevent bird extinctions in the Americas was ReBio União.
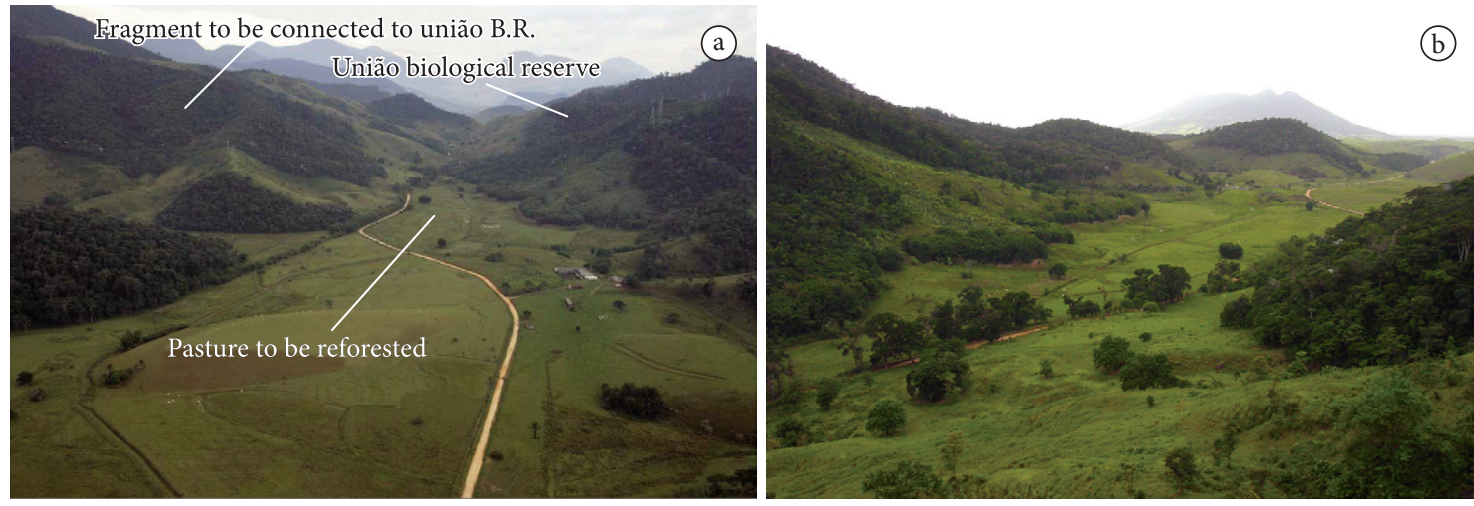

Figure 3. a) Photograph looking north across the gap between União Biological Reserve and adjacent forest areas. Forest fragments are surrounded by cattle pasture. b) Photograph from 2002, looking south across the future corridor region toward the Morro de São João. More recent photographs show this area filling in with trees, now that cattle have been removed. 
The reserve was isolated and we needed to restore connectivity in the landscape, particularly to other conservation units such as the Parque Estadual dos Três Picos. A first step was creating the Fazenda Dourada corridor. Fundamental to that success was that we had a clear and compelling case for action, a story easily understood by non-scientists (i.e., the people generally paying for conservation). Importantly, we had the GIS maps to communicate the message to people ranging from children to scientists to government officials. Anyone can understand a good map, but most people cannot understand a scientific paper. This is crucial, because the vast majority of people involved in conservation are not scientists. The audience determines the needed product.

We believe our maps played a vital role in the successful application of Associação Mico-Leão-Dourado to the IUCN National Committee of the Netherlands and in convincing donors to contribute to SavingSpecies. That successive satellite images, available freely through Google Earth, show the recovery of forest in the corridor only helps to emphasize the geographical transparency of this effort.

Some caveats: First, how sensible were our actions given that we relied only on bird data to set priorities? That we know so much about birds, their distributions, and their rate of loss from small habitat fragments means we could not have repeated this work on any other taxa. Yet that does not mean that bird priorities will be priorities for other species. We found it interesting that our choice was also a top priority for the Associação Mico-Leão-Dourado. This organization focuses on one species (of mammal!) but of course energetically protects many other species in the forests where it lives.

In addition, our choice makes sense in the broad context of biodiversity. The lowlands of the Atlantic Forest have lost proportionately more habitat than upland areas. Habitat fragments lose all types of species, not just birds. Reconnecting forest fragments in the Atlantic Forest is surely a sensible priority for all species, even those about which we know nothing. Second, now that we have achieved our top priority, what about others? Figure 2 shows that lowland habitats in general, and especially those at the eastern edge of the map, are all important. Many efforts are underway to protect and restore these habitats too. We can give some examples. Others have taken actions to expand the boundaries of Parque Estadual dos Três Picos, such as Reserva Ecológica de Guapiaçú (REGUA), which in addition to protecting species and habitats in Três Picos, is also buying neighboring land to add to its own reserve. Several local NGOs are also committed and acting to preserve, regenerate and reconnect parts of the Atlantic Forest in the state, including the region around ReBio União and Parque Estadual dos Três Picos. The Associação Mico-Leão-Dourado has been particularly active in this region and there have been many private actions, with people protecting part of their land through Private Natural Heritage Reserves (RPPNs). These last actions have been extremely important in the state, particularly in the neighborhood of ReBio União and ReBio Poço das Antas, where the golden lion tamarins are mainly established.

Besides the efforts of INEA to expand Parque Estadual dos Três Picos, which will protect several threatened species on the borders of the Park and help connect this area with ReBio União, other official actions to protect habitats and species are being taken in the region. One is the expansion of the Reserva Biológica de Araras (located in the western part of Figure 2) to twice its original size, an action likely to aid protection of the endemic, rare and threatened bird Tijuca condita, recently recorded at this reserve (Alves et al. 2008). INEA has also created new conservation units in the region, such as Parque Estadual da Costa do Sol, a state park officially created in April 2011. It will protect important areas of restinga where Formicivora littoralis, a Critically Endangered bird endemic to this habitat and to Rio de Janeiro state, currently occurs.

There are also wider efforts across the Atlantic Forest in areas that perhaps do not have the same numbers of threatened species as this area, but nonetheless still have many threatened species. Finally, more widely, there are other areas with concentrations of threatened species - the Northern Andes is one. Conservation mapping of these areas is an on-going effort within our group. Preliminary results suggest that once again, restoring connectivity between now-isolated fragments may be a very effective solution.

\section{Acknowledgements}

We thank all the organizations and people who are making efforts to protect habitats and species of the Atlantic Forest and in the state of Rio de Janeiro. We particularly thank André Ilha (from the State Environmental Institute Instituto Estadual do Ambiente - INEA) for his efforts in implementing conservation actions in the state, and for sending us information about those efforts. We would also like to thank the many authors of this special issue and the editors who made it possible. The authors received research grants while writing this paper, including from CNPq (Process $n^{\circ} 308792 / 2009-2$ ) and FAPERJ (Process $\mathrm{n}^{\circ}$ E-102.868/2008) to MASA, and a NASA Biodiversity Grant (ROSES-NNX09AK22G) to CNJ.

\section{References}

Alves MAS et al., 2009a. Região de Petróleo e Gás Natural. In: Bergallo HG et al. (eds.). Estratégias e ações para a conservação da biodiversidade no Estado do Rio de Janeiro. Rio de Janeiro: Instituto Biomas. p. 303-312. 
Alves MAS et al., 2009b. Aves nos remanescentes florestais de Mata Atlântica e ecossistemas associados do Rio de Janeiro. In: Bergallo HG et al. (eds.). Estratégias e ações para a conservação da biodiversidade no Estado do Rio de Janeiro. Rio de Janeiro: Instituto Biomas. p. 193-208.

Alves MAS et al., 2008. Mapping and exploring the distribution of the Vulnerable grey-winged cotinga Tijuca condita. Oryx, 42:562-566. http://dx.doi.org/10.1017/ S0030605308001014

Anderson A \& Jenkins CN, 2006. Applying nature's design: corridors as a strategy for biodiversity conservation, New York: Columbia University Press.

Bencke GA et al., 2006. Áreas Importantes para a Conservação das Aves no Brasil. São Paulo: SAVE Brasil. Parte I - Estados do Dominínio da Mata Atlântica.

Brooks TM, Pimm SL \& Oyugi JO, 1999. Time lag between deforestation and bird extinction in tropical forest fragments. Conservation Biology, 13:1140-1150. http:// dx.doi.org/10.1046/j.1523-1739.1999.98341.x

Dean W, 1996. With broadax and firebrand: the destruction of the Brazilian Atlantic Forest. California: University of California Press.

Ferraz G et al., 2003. Rates of species loss from Amazonian forest fragments. Proceedings of the National Academy of Sciences (U.S.A.), 100:14069-14073. PMid:14614134. PMCid:283547. http://dx.doi.org/10.1073/pnas.2336195100

Fidalgo ECC et al., 2009. Distribuição dos remanescentes vegetais no Estado do Rio de Janeiro. In: Bergallo HG et al. (eds.). Estratégias e ações para a conservação da biodiversidade no Estado do Rio de Janeiro. Rio de Janeiro: Instituto Biomas. p. 91-99.

Fundação SOS Mata Atlântica \& Instituto Nacional de Pesquisas Espaciais, 2010. Atlas dos remanescentes florestais da Mata Atlântica, período 2008-2010: dados parciais dos estados avaliados até maio de 2010. São Paulo: Fundação SOS Mata Atlântica.

Harris GM, Jenkins CN \& Pimm SL, 2005. Refining biodiversity conservation priorities. Conservation Biology, 19:1957-1968. http://dx.doi.org/10.1111/j.1523-1739.2005.00307.x

Instituto Chico Mendes de Conservação da Biodiversidade - ICMBio, 2008. Plano de Manejo da Reserva Biológica União. Brasília: Ministério do Meio Ambiente, ICMBio.

International Union for Conservation of Nature - IUCN, 2010. IUCN Red List of Threatened Species. version 2010.1. Available from: <http://www.iucnredlist.org >. Access in: 11 mar. 2010.

Jenkins CN, 2003. Importância dos remanescentes de Mata Atlântica e dos corredores ecológicos para a preservação e recuperação da avifauna do estado do Rio de Janeiro. In: Fundação CIDE. Índice de Qualidade dos Municípios - Verde II. Rio de Janeiro: Fundação CIDE.

Jenkins CN \& Pimm SL, 2006. Definindo prioridades de conservação em um hotspot de biodiversidade global. In:
Rocha CFD et al. (orgs.). Biologia da conservação: essências. São Carlos: RiMa Editora.

Jenkins CN, Alves MAS \& Pimm SL, 2010. Avian conservation priorities in a top-ranked biodiversity hotspot. Biological Conservation, 143:992-998. http://dx.doi.org/10.1016/j. biocon.2010.01.014

Joppa LN et al., 2011a. How many species of flowering plants are there? Proceedings of the Royal Society B, 278:554-559. PMid:20610425. PMCid:3025670. http://dx.doi.org/10.1098/ rspb.2010.1004

Joppa LN et al., 2011b. Biodiversity hotspots house most undiscovered plant species. PNAS, 108 (46). http://dx.doi. org//10.1073/pnas.1109389108

Laurance WF et al., 2011. The fate of Amazonian forest fragments: A 32-year investigation. Biological Conservation, 144:56-67. http://dx.doi.org/10.1016/j.biocon.2010.09.021

Manne LL, Brooks TM \& Pimm SL, 1999. Relative risk of extinction of passerine birds on continents and islands. Nature, 399:258-261. http://dx.doi.org/10.1038/20436

Manne LL \& Pimm SL, 2001. Beyond eight forms of rarity: which species are threatened and which will be next? Animal Conservation, 4:221-230. http://dx.doi.org/10.1017/ S1367943001001263

Myers $\mathrm{N}$ et al., 2000. Biodiversity hotspots for conservation priorities. Nature, 403:853-858. PMid:10706275. http:// dx.doi.org/10.1038/35002501

Olson DM et al., 2001. Terrestrial ecoregions of the world: a new map of life on Earth. Bioscience, 51:933-938. http:// dx.doi.org/10.1641/0006-3568(2001)051[0933:TEOTW A]2.0.CO;2

Parker III TA, Stotz DF \& Fitzpatrick JW, 1996. Ecological and distributional databases. In: Stotz DF et al. (eds.). Neotropical bird ecology and conservation. Chicago: University of Chicago Press. p. 113-436.

Peterson AT, Papes M \& Eaton M, 2007. Transferability and model evaluation in ecological niche modeling: a comparison of Garp and Maxent. Ecography, 30:550-560.

Pimm SL \& Jenkins CN, 2005. Sustaining the variety of life. Scientific American, 293(3):66-73. PMid:16121856. http:// dx.doi.org/10.1038/scientificamerican0905-66

Pimm SL \& Jenkins CN, 2010. Extinctions and the practice of preventing them. In: Sodhi NS \& Ehrlich PR (eds.). Conservation biology for all. Oxford: Oxford University Press. p. 181-198. http://dx.doi.org/10.1093/acprof :oso/9780199554232.003.0011

Pimm SL et al., 2010. How many endangered species remain to be discovered in Brazil? Natureza \& Conservação, 8:71-77. http://dx.doi.org/10.4322/natcon.00801011

Purvis A et al., 2000. Predicting extinction risk in declining species. Proceedings of the Royal Society B, 267:1947-1952. PMid:11075706. PMCid:1690772. http://dx.doi.org/10.1098/ rspb.2000.1234

Ribeiro MC et al., 2009. The Brazilian Atlantic Forest: How much is left, and how is the remaining forest 
distributed? Implications for conservation. Biological Conservation, 142:1141-1153. http://dx.doi.org/10.1016/j. biocon.2009.02.021

Ridgely RS et al., 2007. Digital distribution maps of the birds of the Western Hemisphere. version 3.0. Arlington: NatureServe.

Rocha CFD et al., 2003. A biodiversidade nos grandes remanescentes florestais do Estado do Rio de Janeiro e nas restingas da Mata Atlântica. São Carlos: RiMa Editora. 160 p.
Rocha CFD et al., 2006. Ecological corridors and conservation of biodiversity. In: Rocha CFD et al. (orgs.). Biologia da conservação: essências. São Carlos: RiMa Editora.

Vale MM et al., 2007. Abundance, distribution and conservation of Rio Branco Antbird Cercomacra carbonaria and Hoarythroated Spinetail, Synallaxis kollari. Bird Conservation International, 17:245-257. http://dx.doi.org/10.1017/ S0959270907000743

Received: August 2011

First Decision: October 2011

Accepted: November 2011 